\title{
Los atentados sociales y el surgimiento de la violencia individualizada en los conflictos laborales de Barcelona, 1902-1917
}

Juan Cristóbal Marinello Bonnefoy

Universitat Autònoma de Barcelona

Las agresiones personales fueron haciéndose costumbre en las luchas sociales, primero utilizando el rudimentario medio de apedrear a los esquiroles y agredirlos a palos, martillazos y demás procedimientos contundentes. Luego se utilizaron los explosivos, reminiscencia de la actuación anarquista, y finalmente surgió el disparo como perfeccionamiento del ataque, dirigido ya no sólo contra obreros rompehuelgas, sino contra los patronos primero, luego contra las autoridades, $y$ por fin contra todos los que se oponían a la parte que practicaba la violencia.

Feliciano Baratech ${ }^{1}$

El testimonio de Feliciano Baratech, uno de los fundadores del Sindicato Libre, describe una evolución demasiado esquemática de la violencia sindical en Barcelona a lo largo de las dos primeras décadas del siglo XX, aunque logra sintetizar en pocas palabras algunas de las transformaciones fundamentales que sufrió el fenómeno. Durante este período, la Ciudad Condal representó el principal foco de conflictividad en el Estado español, destacando hitos como el terrorismo de comienzos de siglo, la Semana Trágica o las huelgas generales de 1902, 1917 y 1919. Más allá de estos grandes episodios, que llevaron a Barcelona a ser conocida

${ }^{1}$ F. Baratech: Los Sindicatos Libres de España, Cortet, Barcelona, 1927, p. 43. 
en los ambientes ácratas internacionales como la "Rosa de Fuego", la ciudad vivió también en forma periódica largos conflictos sindicales que afectaban a miles de trabajadores, decididamente menos espectaculares, pero que también podían alcanzar niveles de violencia muy elevados.

Hasta 1917 las agresiones sindicales fueron un fenómeno más bien excepcional y limitado a algunos conflictos con características particulares. Los efectos derivados de la Primera Guerra Mundial contribuyeron a modificar sensiblemente esta situación, fomentando la movilización de los trabajadores y creando las condiciones para el espectacular crecimiento de la anarcosindicalista Confederación Nacional del Trabajo (CNT). La aparición de una poderosa central basada en sindicatos industriales y de ideología netamente revolucionaria, contribuyó a polarizar el conflicto social en la ciudad. Las actuaciones del movimiento obrero se hicieron cada vez más virulentas, al igual que las respuestas por parte de la patronal y las autoridades gubernativas y militares. Entre 1918 y 1923, Barcelona vivió así una época de violencia extrema, conocida tradicionalmente con el nombre de pistolerismo. Según cálculos de Albert Ballcells, durante estos años 951 personas fueron afectadas por agresiones relacionadas con la lucha sindical, de las cuales fallecieron $261 .^{2}$

Rápidamente, el concepto de "atentado social” se popularizó para definir el tipo de ataques que caracterizaron al pistolerismo. Autores como Miguel Sastre i Sanna o Josep Maria Farré i Moregó llevaron adelante importantes esfuerzos para realizar una aproximación cuantitativa al fenómeno, recopilando cientos de episodios de violencia que se habían producido en Barcelona y otras ciudades. Si bien bajo este concepto se mezclaron en forma ambigua distintas tipologías de violencia, la noción de atentado social resulta útil para evidenciar un aspecto particular de la violencia en los conflictos laborales de Barcelona. ${ }^{3}$

Por lo general, la mayor propensión del movimiento obrero barcelonés a utilizar la violencia ha sido interpretada como la consecuencia de la incapacidad del Estado y los empresarios catalanes para asumir con naturalidad las relaciones con los sindicatos. Para Angel Smith, los principales hechos de violencia de comienzos de siglo se explican en gran medida por la dureza de las relaciones laborales en Catalunya. La violencia habría constituido un eje importante de la acción colectiva de los trabajadores, en un contexto en el que las relaciones laborales no

\footnotetext{
${ }^{2}$ A. Balcells: El pistolerisme. Barcelona (1917-1923), Pórtic, Barcelona, 2009, pp. 55-58.

${ }^{3}$ Las estadísticas recopiladas en: M. Sastre: La esclavitud moderna, martirologio social. Relación de los atentados y actos de sabotage cometidos en Barcelona, y bombas y explosivos hallados desde junio de 1910 hasta junio de 1921, Ribó, Barcelona, 1921; y J. M. Farré: Los atentados sociales en España, estudio sociológicojurídico. Estadística de los cometidos desde el 1 de enero de 1917 hasta 1 de enero de 1922, especial de los cometidos en Barcelona desde 1 de enero de 1910 hasta 1 de enero de 1922, Casa Faure, Madrid, 1922.
} 
se encontraban institucionalizadas, por lo que la movilización de masas era una herramienta fundamental en las huelgas. ${ }^{4}$

Ahora bien, desde nuestra perspectiva, en Barcelona se desarrolló un tipo de violencia que presentó características específicas, por lo que se podría decir que la Ciudad Condal no sólo fue un escenario más violento, sino que también fue un contexto de violencia diferenciado. Los atentados sociales fueron la razón esencial de esta singularidad, en cuanto la presencia de ataques individualizados contrastaba con el carácter colectivo que mantuvo el fenómeno en otros contextos. Entendemos violencia individualizada como un tipo de agresión dirigida específicamente contra personas concretas y definidas, a diferencia de la violencia derivada de encuentros espontáneos o acciones de masas. Este tipo de ataques se hizo presente en Barcelona desde comienzos del siglo XX, asumiendo un carácter cada vez más organizado a partir de 1910.

El objetivo del presente artículo es reconstruir el surgimiento de esta violencia individualizada en Barcelona a través del análisis de tres momentos decisivos. En primer lugar, el viraje en la política de orden público del gobierno tras la huelga general de 1902, pasando de una lógica reactiva a una preventiva. Esta nueva actitud permitió controlar la acción masiva de los trabajadores en las calles, pero con el efecto no deseado de multiplicar la violencia a través de la acción de pequeños núcleos de huelguistas que escapaban al control policial. En segundo lugar, la polarización social tras la Semana Trágica y la radicalización del llamado sindicalismo de acción directa, que tuvo como consecuencia la aparición de un reducido número de huelgas muy violentas durante los años anteriores a la Primera Guerra Mundial. Por último, nos referiremos a las principales características de la conflictividad sindical en el Ramo del Agua y entre los contramaestres del textil, que originaron los primeros atentados contra empresarios, alcanzando un carácter sistemático durante la segunda mitad de 1917. Cabe destacar, que nuestro artículo no se propone realizar la historia del origen del pistolerismo, ni tampoco presentarlo como el resultado necesario de una serie determinada de factores. A través del análisis del surgimiento de la violencia sindical individualizada, apuntamos a reconstruir un fenómeno concreto que contribuyó, eso sí, a generar un caldo de cultivo fundamental para comprender los sucesos posteriores.

\section{Delitos y atentado sociales}

Entre finales de junio y comienzos de julio de 1918, se desarrolló el congreso de la Confederación Regional del Trabajo — es decir, la CNT en Catalunyaconocido tradicionalmente como "Congreso de Sants". El principal acuerdo al-

${ }^{4}$ A. Smith: Angel. Anarchism, revolution and reaction. Catalan labor and the crisis of the Spanish State, 1898-1923, Berghahn, Nueva York/Oxford, 2007, p. 183. 
canzado entre los delegados participantes fue el de establecer un nuevo modelo organizativo basado en ramos de actividad industrial, superando de este modo las limitaciones del tradicional societarismo de oficio. La creación y expansión de los Sindicatos Únicos durante los meses siguientes se dio en un contexto de intensa conflictividad laboral, a lo que se sumaban las esperanzas y temores desencadenados por la revolución rusa y las distintas revueltas europeas que acompañaron el final de la guerra mundial. El creciente poder de los sindicatos en Barcelona, expresado a través de una inédita capacidad de control sobre el mercado de trabajo, se desplegó en un clima de creciente polarización y radicalización, que generó varios episodios de violencia contra esquiroles, obreros no sindicalizados y empresarios. En este sentido, la situación de finales de 1918 constituía un claro preludio a lo que sucedería a lo largo de los años posteriores. La secuencia de episodios violentos comenzaba a distanciarse de la actividad huelguística y a consolidarse como un fenómeno en sí, que la prensa definió a través de una etiqueta que tendrá bastante éxito: la de crímenes o atentados sociales. ${ }^{5}$

El concepto de atentado social aplicado a la violencia sindical era un elemento novedoso, aunque se apoyaba en una categoría que presentaba una tradición más larga: los delitos sociales. El delito social ingresó en el lenguaje jurídico durante la segunda mitad del siglo XIX, impulsado por algunos miembros del Instituto de Derecho Internacional como respuesta a la "propaganda por el hecho" anarquista. El objetivo era evitar que los anarquistas pudiesen gozar de los beneficios que la legislación europea garantizaba a los delincuentes políticos en materia de extradición. El argumento central era que la represión no podía ser responsabilidad única del Estado donde se cometía el hecho, ya que el terrorismo anarquista era un delito contra el conjunto de la sociedad — por ende social - y no contra una forma determinada de gobierno, como en el delito político. En el Estado español, este planteamiento tuvo cierta difusión a finales de siglo, siendo defendido incluso por Antonio Cánovas para justificar la necesidad de leyes especiales. Sin embargo, esta concepción del delito social se mantuvo fundamentalmente dentro de los márgenes estrechos del derecho internacional, siendo ampliamente superada en el ámbito de la opinión pública por la noción de terrorismo. ${ }^{6}$

Algunos años después, el delito social reapareció con fuerza en el panorama español, impulsado por el movimiento obrero y los partidos republicanos con un significado muy diferente al anterior. La agitación sindical de comienzos de siglo había traído como consecuencia la detención de una gran cantidad de trabajado-

${ }^{5}$ Sobre el Congreso de Sants y los Sindicatos Únicos, ver P. Gabriel: Classe obrera i sindicats a Catalunya, 1903-1920, Tesis doctoral, Universitat de Barcelona, 1981, pp. 617-646; y M. Lladonosa: El Congrés de Sants, Nova Terra, Barcelona, 1975.

${ }^{6}$ Con respecto al delito social: E. Cuello Calón: «Sobre la extradición de los delitos políticos y de los delitos sociales», Revista general de legislación y Jurisprudencia, año 70 tomo 140 (1922), pp. 481-494. El discurso de Antonio Cánovas del Castillo en Revista de España, tomo CXLIII (1892), pp. 166-195. 
res, lo que generó distintas campañas para la liberación de los presos por "delitos sociales". Inicialmente, el delito social era entendido como un acto ilegal derivado de movilizaciones populares que no respondían a un objetivo explícitamente político; sin embargo, cada vez se identificaría más estrechamente con la acción sindical, inspirando algunas amnistías que comprendían a los delitos cometidos en las huelgas. En definitiva, a través de la noción de atentado social se fundían dos imágenes poderosas y de una larga tradición: el terrorismo anarquista y la violencia obrera. ${ }^{7}$

El mundo intelectual también asumió el concepto de delito social en sus intentos para definir la violencia y ofrecer posibles salidas a una situación de enfrentamiento que se había transformado en crónica. Destacaron en este ámbito, los anteriormente mencionados Miguel Sastre y Josep Maria Farré, autores que coincidieron en dar particular relevancia a la recopilación de una minuciosa estadística de los episodios de violencia. Para Eduardo González Calleja, esta operación se enmarcaba en la tradición del positivismo francés e italiano, que desde finales del siglo XIX había ofrecido una herramienta para atenuar la incertidumbre respecto a la conflictividad social, a través de la "proliferación de unos saberes positivizados que mediante aproximaciones experimentales y estadísticas trataban de objetivar la realidad y constatar la existencia y etiología de una criminalidad específica, con el fin de prescribir la terapia médica, social y penal más adecuada". ${ }^{8}$

Farré i Moregó fue el que más relevancia otorgó al concepto de atentado social, utilizándolo como título de su estudio sociológico-jurídico publicado en 1922. El prólogo de la obra lo firmaba el destacado jurista Quintiliano Saldaña, que ejerció una notable influencia sobre Farré y que definía el atentado social como "todo delito grave o crimen cometido con ocasión de luchas sociales, y por motivos de clase, corporación o profesión". ${ }^{9}$ Para Farré, el fenómeno de la violencia estaba estrechamente relacionado con la matriz anarquista del sindicalismo revolucionario español, el cual habría desarrollado el atentado social como una forma especial de acción directa, ausente del todo en el sindicalismo europeo. En este sentido, dicho autor consideraba que Barcelona representaba un caso particular, a la vez que el principal foco irradiador de la violencia hacia el resto del Estado. En palabras suyas,

Si bien la lucha social que aflige a Barcelona obedece a un compás universal, no es posible dudar - ya hemos intentado demostrarlo— que ha adquirido en Barcelona formas especiales de destacada personalidad. El anarquismo desarrollado en la masa obrera (...) creó, al aparecer

${ }^{7}$ Al respecto, ver A. Fiestas Loza: Los delitos políticos (1808-1936), Universidad de Salamanca, Salamanca, 1977, pp. 279-283.

${ }^{8}$ E. González Calleja: «La violencia política en la España del siglo XX: un balance historiográfico», Mélanges de la Casa de Velázquez [En línea], 38-2 (2008), consultado el 24 de octubre de 2015. URL: http://mov.revues.org/627.

${ }^{9}$ Q. Saldaña: El atentado social (doctrina y legislación), Góngora, Madrid, 1927, pp. 37-38. 
la idea nueva [el sindicalismo revolucionario], un producto mimético: el "atentado" como medio de acción, a través de la "propaganda por el hecho" anarquista, heterónima, pero de idéntica significación práctica que el atentado. ${ }^{10}$

Como resulta evidente, la noción de atentado social presenta varias limitaciones, constituyendo un concepto parcial que fue utilizado en su época para criminalizar al movimiento obrero. No obstante, hemos considerado oportuno rescatarlo por dos razones. En primer lugar, lo "social"-que en esta época se entendía fundamentalmente como sinónimo de sindical—permite definir un ámbito de acción concreto que presenta una serie de características y lógicas propias que dificilmente pueden ser subsumidas, como suele suceder, en las categorías de violencia política o acción colectiva. Por otra parte, consideramos que el atentado social sintetiza las principales particularidades que asumió la violencia ligada al movimiento obrero en Barcelona. En este sentido, entenderemos por atentado social en el presente artículo aquellos ataques premeditados y con cierto grado de organización, realizados con medios potencialmente letales, contra personas concretas y con una motivación —al menos en apariencia- sindical.

\section{REPRESIÓN ESTATAL E INHIBICIÓN DE LA ACCIÓN COLECTIVA}

A comienzos del siglo XX, el concepto utilizado generalmente para definir la actuación violenta de los huelguistas fue el de "coacción"; una categoría ambigua ya que no establecía fronteras claras entre propaganda, amenazas y violencia material. Las sociedades obreras asumían estas presiones como una forma de legítima defensa del derecho a la huelga, mientras que las autoridades tendían a considerar coacción cualquier interferencia con la "libertad de trabajo", tanto violenta como pacífica. De este modo, nunca se llegó a una definición compartida y convincente con respecto a los límites de la acción sindical. Si la coacción era el verbo en que se conjugaba la violencia, el sujeto por excelencia eran los "grupos"; otra categoría que tendía a esconder realidades diferentes bajo una aparente homogeneidad del lenguaje, considerando que durante estos años los actores de la violencia sindical sufrieron profundas transformaciones. A comienzos de siglo los enfrentamientos tendían a involucrar a piquetes de decenas o cientos de participantes, en los que con frecuencia intervenían personas ajenas al conflicto, como mujeres y adolescentes. Con posterioridad, la violencia fue perdiendo este carácter colectivo, centrándose en la actuación de grupos pequeños de jóvenes huelguistas. Por el contrario, los objetivos de la violencia se mantuvieron estables, centrándose casi exclusivamente en los obreros que no secundaban el paro y en los esquiroles contratados para sustituir a los huelguistas. Los ataques contra empresarios fueron

${ }^{10}$ J. M. Farré: Los atentados sociales..., op. cit., p. 106. En cursivas en el original. 
un hecho excepcional, limitado generalmente a pequeños patronos que podían trabajar por su cuenta, cumpliendo un rol similar al del esquirol. ${ }^{11}$

Hacia finales de la década de 1890, el movimiento obrero en Cataluña experimentó un importante crecimiento que se prolongó durante los primeros años del nuevo siglo. La agitación se extendió principalmente entre los trabajadores textiles de la valle del Ter, donde tras intensos enfrentamientos con los empresarios, las organizaciones obreras se desmoronaron. En Barcelona, la movilización sindical también atravesó una fase creciente, especialmente en los sectores de la construcción, los transportes y la metalurgia. La gran mayoría de las huelgas en la ciudad se desarrollaban sin incidentes, y la formación de piquetes era tolerada mientras se mantuviesen a distancia y en actitud pacífica. Evidentemente, la acción de los huelguistas podía provocar en ocasiones enfrentamientos violentos. Por ejemplo, en julio de 1900 unos 200 fundidores en huelga se reunieron en las cercanías de la fábrica Planas para intentar evitar el ingreso de rompehuelgas. Ambos bandos se acabaron enfrentando, resultando un esquirol herido de un garrotazo en la cabeza. Al llegar la policía, detuvo a algunos huelguistas que fueron liberados a la fuerza por sus compañeros. ${ }^{12}$

La principal desviación con respecto a esta dinámica estuvo determinada por las campañas realizadas por propagandistas anarquistas a favor de la huelga general. A finales del siglo XIX, la huelga general constituía uno de los ejes centrales del sindicalismo revolucionario francés, difundiéndose también, gracias a la influencia de Francesc Ferrer i Guàrdia, en el movimiento libertario de Barcelona. Los anarquistas apostaron por la radicalización de las luchas sectoriales, intentando extenderlas al conjunto del movimiento obrero. Dicha táctica alcanzó sus primeros frutos en mayo de 1901, cuando una huelga de empleados de tranvías, ómnibus y ferrocarriles suburbanos derivó en un paro general; sin embargo, tras la proclamación del estado de guerra el Ejército controló rápidamente la situación. A lo largo del conflicto, se verificaron numerosos enfrentamientos colectivos, en los que destacó la amplia participación de mujeres, niños y adolescentes. Dichos actores no eran huelguistas, por lo que sus acciones contribuían a desbordar el estrecho marco sindical para transformarse en manifestaciones populares de apoyo hacia los trabajadores en conflicto. A diferencia del piquete sindical, la represión de estos grupos situaba a las autoridades en una situación compleja, ya que existía una cierta reticencia respecto al empleo con dureza de las fuerzas de orden público contra mujeres y niños. Por otra parte, su movilidad y habilidad para mimetizarse era muy superior a la de los huelguistas, generalmente identificables debido a sus

\footnotetext{
${ }^{11}$ Para una discusión más detallada sobre las características de la violencia sindical en Barcelona a comienzos del siglo XX, ver J. C. Marinello: Sindicalismo y violencia en Catalunya 1902-1919, Tesis doctoral, Universitat Autònoma de Barcelona, 2014, pp. 133-146.

${ }^{12}$ La Veu de Catalunya (Barcelona), 8 de julio de 1900, edición de la mañana, p. 2. Con respecto a la movilización sindical de comienzos de siglo, ver A. Smith: Anarchism..., op. cit., pp. 76-127.
} 
ropas de trabajo. Así lo reconocía, por ejemplo, el Capitán general Manuel Delgado Zuleta, al afirmar en pleno estado de guerra que:

No ha sido posible evitar en absoluto las coacciones, dada la forma en que éstas se vienen ejerciendo, pues en su mayor parte están formadas por grupos de mujeres y niños, que eluden fácilmente [...] la acción de las tropas, a pesar de estar en constante movimiento y subdivididas en parejas $y$ fracciones de mayor o menor fuerza. ${ }^{13}$

El segundo intento resultó mucho más exitoso. El 17 de febrero de 1902, la gran mayoría de las sociedades obreras de la ciudad iniciaron una paralización en solidaridad con los metalúrgicos, que habían abandonado el trabajo en diciembre. Según la estimación más aceptada, la huelga general involucró a alrededor de 80.000 trabajadores, extendiéndose también a otras poblaciones de Cataluña durante los días siguientes. Tras los primeros enfrentamientos con la Guardia civil, el Gobernador resignó el mando a los militares, que llegaron incluso a utilizar ametralladoras contra los huelguistas. La represión y el desgaste significaron un rápido declive del movimiento, retomando los obreros el trabajo tras una semana sin conseguir ninguna de sus demandas. Exceptuando algunos incidentes puntuales, la huelga resultó relativamente pacífica considerando el número de trabajadores involucrados. $\mathrm{Al}$ respecto, uno de los principales protagonistas, el anarquista Ignaci Clariá, señaló que "los huelguistas iban mal armados y en pequeños grupos, que no podían ni querían batirse con la tropa". ${ }^{14}$ Por su parte, el historiador Joaquín Romero Maura considera que la huelga causó un impacto mucho mayor con respecto a la acción real de los obreros en las calles, resultando, según un recuento del Foment del Treball Nacional, 12 muertos y 44 heridos, cifra muy lejana del centenar de muertos y 300 heridos recogidos por Alfonso Colodrón a través de la prensa extranjera. ${ }^{15}$

A pesar de la derrota, la huelga general de febrero de 1902 significó una imponente exhibición de la capacidad de movilización de los sindicatos barceloneses, a la vez que una seria demostración del potencial que la extensión de los conflictos laborales ofrecía para el anarquismo. En este sentido, la huelga general marcó un punto de inflexión en la actitud del Estado con respecto a la acción sindical en la Ciudad Condal. Hasta entonces, la militarización del orden público y el abuso de los estados de excepción habían permitido al régimen sobrevivir sin demasiadas

${ }^{13}$ La Correspondencia de España (Madrid), 10 de mayo de 1901, p. 3. Otros episodios relevantes protagonizados por mujeres y adolescentes en La Publicidad (Barcelona), 3 de mayo de 1901, ed. de la mañana, p. 2 y 7 de mayo de 1901, ed. de la noche, p. 3.

${ }^{14}$ Cit. en X. Cuadrat: Socialismo y anarquismo en Cataluña (1899-1911). Los orígenes de la CNT, Ediciones de la Revista de Trabajo, Madrid, 1976, p. 82.

${ }^{15}$ J. Romero Maura: La Rosa de Fuego. El obrerismo barcelonés de 1899 a 1909, Alianza, Madrid, 1989, pp. 206-218. Sobre la huelga general de 1902, ver también A. Colodrón: «Aportación al estudio de la huelga general (la huelga general de Barcelona de 1902)", Revista de Trabajo, 33 (1971), pp. 67-119; y A. Duarte: «Entre el mito y la realidad. Barcelona, 1902», Ayer, 4 (1991), pp. 147-168. 
zozobras; sin embargo, tras la derrota de 1898, el ambiente regeneracionista que se respiraba exigía soluciones más acordes con la realidad europea. Las autoridades tomaron consciencia de la debilidad del Estado para contener las movilizaciones populares dentro de la legalidad ordinaria vigente, lo que generó una sensación de vulnerabilidad que explica la prolongación del estado de guerra hasta octubre y de la suspensión de las garantías hasta enero de 1903. En agosto, el Ministro de Gobernación Segismundo Moret habló sobre la situación del país ante el Consejo de Ministros, comunicando

a sus compañeros la imposibilidad de gobernar en las condiciones legales ordinarias sin necesidad de acudir al estado de guerra o a la suspensión de garantías, sin una ley de seguridad análoga a la que tienen todos los países de Europa, y que permita a las autoridades civiles ejercer, no sólo la vigilancia para la conservación del orden y el respeto a los derechos, sino la coerción indispensable sobre los que no respetan las leyes o han sido ya objeto de sentencia de los Tribunales. ${ }^{16}$

En diciembre de 1902, el comienzo de un nuevo turno de gobierno para los conservadores significó el nombramiento de Antonio Maura como Ministro de la Gobernación. Maura tenía como objetivo lograr un profundo viraje en la política de orden público de la Restauración. Para Eduardo González Calleja, Maura proponía un "rearme de la autoridad gubernativa", para lo cual a los pocos días de asumir el cargo se reunió con los nuevos gobernadores, exponiendo "no sólo un completo programa de acción, sino toda una filosofia de gobierno, condensada en tres principios básicos: la neutralidad de los delegados gubernativos en las luchas sociales y políticas, el imperio de la ley como bien público y el uso enérgico pero legítimo de la fuerza en caso de rebelión". ${ }^{17}$

La apuesta de Maura debió afrontar un prolongado desafío desde Barcelona durante 1903, concluyéndose con un éxito para el político mallorquín; si bien, al mismo tiempo, la nueva política generó algunos efectos no deseados que tuvieron consecuencias de larga duración. Desde comienzos de año, la agitación sindical en la ciudad fue creciendo luego del obligado hiato impuesto por el estado de guerra. En febrero, los anarquistas intentaron con insistencia repetir la experiencia del año interior, pero las divisiones en el seno de las sociedades obreras, así como las maniobras del Gobernador civil y el nuevo Ministro de Gobernación, significaron el fracaso de una nueva huelga general. A pesar de ello, distintas sociedades de oficio comenzaron a movilizarse en pos de sus reivindicaciones laborales, alcanzando su punto más álgido durante el verano, cuando los distintos conflictos

${ }^{16}$ La Correspondencia Militar (Madrid), 25 de agosto de 1902, p. 2. Con respecto al rol de los militares en el orden público ver M. Ballbé: Orden público y militarismo en la España constitucional (1812-1983), Alianza, Madrid, 1985.

${ }^{17}$ E. González Calleja: La razón de la fuerza: orden público, subversión y violencia política en la España de la Restauración, 1875-1917, CSIC, Madrid, 1998, p. 322. 
abiertos llegaron a reunir decenas de miles de huelguistas. Las precauciones adoptadas por el Gobernador civil fueron imponentes, desplegando todas las fuerzas a su disposición en forma coordinada para lograr controlar de manera eficaz el territorio, ocupando los puntos estratégicos de la ciudad y cacheando los obreros sospechosos. Aun así, pequeños grupos de huelguistas lograban actuar saboteando carros, asaltando talleres y agrediendo a esquiroles. A comienzos de agosto, el movimiento libertario convocó una huelga general con el objetivo de lograr un amplio indulto para los presos políticos y sociales. El paro fracasó, por una parte, debido a la falta de apoyo entre las bases que certificaba el temporal divorcio entre los trabajadores barceloneses y las tácticas anarquistas y, por otra, gracias a las medidas preventivas del Gobernador civil Carlos González Rothwoss, el cual, entre otras cosas, anunció que consideraría a los huelguistas como culpables del delito de sedición. ${ }^{18}$

El Estado había logrado evitar el peligro de repetir la situación de febrero de 1902 sin apelar al tradicional recurso del estado de guerra y la suspensión de garantías, si bien la victoria era engañosa en cuanto se había forzado la ley para transformar lo excepcional en legal al considerar el movimiento como sedicioso. Además, el Estado respondió al desafío incrementando el despliegue de fuerzas de seguridad, con el objetivo de alcanzar un control preventivo que inhibiese la acción colectiva de la clase obrera. Dicho procedimiento alcanzó su punto culminante durante el verano de 1903, cuando la autoridad civil logró, en palabras de Soledad Bengoechea, "obstaculizar la acción de los piquetes, asegurar así la continuación del trabajo mediante la contratación de la numerosa mano de obra sobrante y amedrentar a la clase obrera con el despliegue de las fuerzas de la policía y la guardia civil". ${ }^{19}$ Sin embargo, la actuación estatal tuvo un efecto imprevisto: ante la imposibilidad de intervenir en forma masiva, los trabajadores se organizaron en grupos de reducidas dimensiones, lo que acabó multiplicando exponencialmente la violencia sindical: entre junio y agosto se registraron más de un centenar de episodios de violencia, constituyendo uno de los registros más elevados de las primeras décadas del siglo XX. ${ }^{20}$

A partir de 1904, el movimiento sindical catalán entró en una fase de reflujo que se extendió hasta el final de la década. La irrupción del republicanismo lerrouxista y la crisis económica abrieron una brecha entre los trabajadores barceloneses y

\footnotetext{
${ }^{18}$ Sobre la conflictividad laboral en Barcelona durante 1903, ver M. Sastre: Las huelgas en Barcelona y sus resultados durante el año 1903, Pujol, Barcelona, 1904; y S. Bengoechea: «Conflictividad social en Barcelona durante 1903», en Trabajo y relaciones laborales en la España contemporánea, Mergablum, Sevilla, 2001, pp. 341-354. El bando del Gobernador en La Publicidad (Barcelona), 2 de agosto de 1903, ed. de la noche, p. 2. Un ejemplo del despliegue de fuerzas policiales en la ciudad en La Vanguardia (Barcelona), 23 de junio de 1903, ed. de la tarde, p. 3.

${ }^{19}$ S. Bengoechea: "Conflictividad social en Barcelona...», op. cit., p. 344.

${ }^{20}$ En base a la consulta de la prensa de la época, hemos contabilizado 114 actos de violencia sindical entre el 15 de junio y el 7 de agosto de 1903 .
} 
el movimiento obrero y libertario. En particular, el período 1904-1907 resultó especialmente duro para las sociedades obreras, lo que significó un pronunciado descenso de la conflictividad laboral. De este modo, tras el verano de 1903 la amenaza de una nueva huelga general prácticamente desapareció, pero la presión de las autoridades sobre el movimiento sindical se mantuvo alta, con el objetivo de minar la capacidad de movilización de las sociedades obreras y evitar que fueran utilizadas nuevamente como plataforma de agitación por el anarquismo. ${ }^{21}$

El gobernador González Rothwoss, bajo órdenes del Ministerio de Gobernación, se distinguió durante su mandato por adoptar distintos mecanismos de control sobre las sociedades obreras de la ciudad. La estrategia del Gobernador civil para limitar la influencia anarquista sobre las organizaciones obreras tuvo éxito, aunque también afectó la actividad estrictamente sindical, imponiendo trabas al funcionamiento de unas sociedades de oficio severamente debilitadas por la crisis económica. Por otra parte, González Rothwoss llevó adelante una dura política en contra de la violencia sindical, amenazando con la clausura de sindicatos y la detención de las juntas directivas cuando se verificaban coacciones. El problema es que esta pretensión de limitar las agresiones de los huelguistas se basó en una concepción de la coacción sindical que sobrepasaba el marco legal, ya que no solo se reprimieron las violencias y amenazas, sino cualquier tipo de interferencia con la libertad de trabajo, incluso cuando eran acciones asumidas en forma voluntaria y pacífica. Por ejemplo, prohibió a los barberos la utilización del label para señalar los establecimientos que habían firmado un acuerdo con los trabajadores, llegando a multar a los patronos que exhibían las bases en sus puertas. ${ }^{22}$ Esta concepción ampliada de la coacción sindical, que se centraba más en la actuación preventiva por sospechas que en el castigo de delitos comprobados, generó un sentimiento de agravio y arbitrariedad en el seno del movimiento obrero, deslegitimando el rol de las autoridades gubernativas, el poder judicial y la fuerza pública. Comentando las numerosas detenciones de huelguistas durante 1904, un artículo de $\mathrm{La}$ Publicidad afirmaba lo siguiente:

¿Qué revelan estos hechos? La excesiva complacencia de la autoridad gubernativa al querer hacer méritos ante la clase patronal. Revelan más aún. [...] Surgió hace poco la huelga de obreros barberos-peluqueros. Como siempre, tras la huelga vino la detención a todas luces arbitraria de una treintena de trabajadores del oficio, los cuales han pasado en la cárcel algunas semanas.

${ }^{21}$ Con respecto a la situación del movimiento obrero en Catalunya durante la primera década del siglo XX, ver P. Gabriel: Classe obrera i sindicats..., op. cit.; X. Cuadrat: Socialismo y anarquismo..., op. cit.; A. Smith: Anarchism..., op. cit.; J. Romero Maura: La rosa de fuego..., op. cit.

${ }^{22}$ La Publicidad (Barcelona), 11 de junio de 1904, ed. de la noche, p. 3. Del mismo modo, en 1904 se le prohibió a los marinos depositar su documentación durante la huelga en el local como habían acordado, y se impidió a los constructores de carruajes realizar la misma acción con sus herramientas. Respectivamente en La Publicidad (Barcelona), 4 de febrero de 1904, ed. de la mañana, p. 2 y 14 de enero de 1904, ed. de la noche, p. 3. 
Terminó el conflicto y los detenidos han recobrado su libertad, prueba evidente y palmaria de su inocencia. [...] Quedan en la cárcel algunos obreros basureros, que es de suponer pasarán por las mismos trámites que los demás detenidos. A estos vendrán otros y otros, hasta que la resuelta actitud de los trabajadores quiera acabar con tanta injusticia. ¿Y todavía hay quien se extraña de que entre la masa proletaria germine el espíritu de rebeldía y el ansia de destrucción del organismo social que tantas miserias origina? Precisa consignar que durante los largos años que venimos presenciando la conducción de inocentes obreros a la cárcel, no hemos tenido noticia de haber sido llevado a ella ni un solo fabricante, ni un burgués. ¿Significa algo este detalle? Tal vez sí, pero que lo diga el lector. ${ }^{23}$

Hacia finales de 1904, el terrorismo desplazó definitivamente a la violencia sindical como principal preocupación de las autoridades. La represión se concentró entonces en el movimiento anarquista, por lo que las sociedades obreras dejaron de sufrir un control tan estrecho, coincidiendo además con una pronunciada caída de la conflictividad laboral. El terrorismo desnudó todavía más las falencias de la policía barcelonesa, cuya reforma se transformó en una de las principales prioridades. Los avances más importantes se dieron bajo el mandato del gobernador Ángel Ossorio y Gallardo, nombrado por Antonio Maura, presidente del Gobierno desde enero de 1907. La restructuración mejoró notablemente el servicio, tanto desde el punto de vista cualitativo como cuantitativo, organizando la policía en secciones de distrito que permitían una relación más estrecha con el territorio. A mediados de 1908, el Cuerpo de vigilancia contaba con 400 efectivos y el de seguridad con 800 , es decir, un total de 1.200 policías que superaban con creces los 150 agentes con que disponía Barcelona en 1902. ${ }^{24}$

El mayor número de efectivos y la mejor estructuración de las fuerzas permitieron ejercer un mejor trabajo preventivo con respecto a la violencia, aunque cabe destacar que la situación de la policía barcelonesa durante la Restauración nunca llegó a ser óptima. La presencia de fuerzas en las cercanías de fábricas y talleres en huelga disuadió la conformación de grupos y contribuyó a que durante estos años las agresiones fueran un fenómeno excepcional. Incluso durante las huelgas de oficio, que ofrecían un mayor margen de maniobra para la acción colectiva de los huelguistas, la represión de los cuerpos policiales mantuvo a raya la formación de grupos. Por ejemplo, durante la huelga de sastres de 1908,

Ayer mañana recorrieron también las calles de nuestra ciudad varios grupos de oficiales sastres huelguistas vigilando la entrada de los obreros en los talleres del oficio en que se trabaja, con

${ }^{23}$ La Publicidad (Barcelona), 8 de julio de 1904, ed. de la mañana, p. 2.

${ }^{24}$ Un detallado examen de las fuerzas de los cuerpos de vigilancia y seguridad en La Publicidad (Barcelona), 23 de agosto de 1908, ed. de la mañana, p. 3. La cifra de 1902 se basa en declaraciones del Gobernador Francisco Manzano a El Liberal (Madrid), 31 de marzo de 1902, p. 1. Con respecto al terrorismo de comienzos de siglo, ver A. Herrerín: Anarquía, dinamita y revolución social. Violencia y represión en la España de entre siglos, 1868-1909, Catarata, Madrid, 2011. 
objeto de rogar a aquéllos que les secundasen en el paro. [...] Los agentes de la autoridad seguían de cerca a los huelguistas evitando que formasen grupos demasiado numerosos y en alguna ocasión se vieron precisados a disolverlos por la fuerza; así sucedió en la plaza Real frente a uno de los bazares allí establecidos, donde la policía simuló una carga y detuvo a siete huelguistas $y$ según se dijo, no se dieron gran prisa en obedecer las indicaciones de los agentes. Con tal motivo se originaron algunas carreras, oyéndose bastantes voces $y$ silbidos. ${ }^{25}$

En síntesis, tras la huelga general de 1902 y la oleada de agitación del verano de 1903, la violencia sindical en Barcelona disminuyó, en buena medida debido al reflujo de la movilización sindical y la desarticulación del movimiento societario. Sin embargo, consideramos también que este descenso de la violencia sindical estuvo marcado por la represión de las autoridades y la creciente efectividad de la policía, lo que contribuyó en forma decisiva a inhibir la utilización del piquete, la principal modalidad de acción colectiva para los huelguistas. En definitiva, durante la primera década del siglo XX existió una importante transformación de las políticas represivas en Barcelona. De un modelo fundamentalmente militarizado y reactivo, se pasó a otro centrado en una lógica policial y preventiva, ejerciendo una fuerte presión sobre los huelguistas incluso antes de que se cometieran delitos. Evidentemente, la violencia no fue erradicada de los conflictos laborales, pero se fue escindiendo de la dimensión colectiva, atomizándose en torno a las agresiones aisladas de pequeños grupos de huelguistas.

\section{LAS HUELGAS METALÚRgICAS DE I9IO Y \\ EL SURGIMIENTO DE LOS ATENTADOS SOCIALES}

En julio de 1909 un nuevo estallido social sacudió a Cataluña, pasando a la historia con el nombre de Semana Trágica. El punto de partida fue una huelga general contra la guerra en Marruecos, aunque el movimiento adquirió un carácter insurreccional y anticlerical que se manifestó en la quema de edificios religiosos. En este sentido, la Semana Trágica sobrepasa ampliamente la temática de la violencia sindical, aunque no es posible ignorar que su inicio se enmarcó en una huelga. El gobernador Ossorio consideró que el paro constituía una protesta legítima, por lo que no era necesario militarizar la ciudad como dictaba la lógica preventiva inaugurada en 1903. Del mismo modo, se resistió a resignar el

${ }^{25}$ La Vanguardia (Barcelona), $1^{\circ}$ de mayo de 1908, p. 4. Otro indicio de la mayor eficacia de la policía es el descenso de la criminalidad común durante el mandato de Ossorio mencionado por Joaquín Romero Maura en "Terrorism in Barcelona and its impact on Spanish Politics 1904-1909», Past \& Present, 41 (1968), pp. 173-174. Para un análisis de las reformas policiales en Barcelona durante la primera década del siglo XX, ver E. González Calleja: «La Cataluña ingobernable: el forcejeo por el control del orden público en Barcelona en los prolegómenos de la 'Semana Trágica'», Bulletin d'histoire contemporaine de l'Espagne, 47 (2012), pp. 43-64. 
mando a las autoridades militares, hasta que fue obligado por el Ministro de la Gobernación Juan de La Cierva. Ossorio consideraba que finalmente el Estado era lo suficientemente fuerte para gestionar la movilización social dentro de una normalidad legal e institucional. Una idea que se reveló como un espejismo sustentado en el descenso de la conflictividad laboral durante los años anteriores y en la erosión de las formas tradicionales de acción colectiva sindical debido a una situación fuertemente represiva. La Semana Trágica cerraba así el período iniciado en 1902, destruyendo la ilusión albergada por un sector de la clase política de haber anulado el potencial subversivo de las sociedades obreras. Los sucesos de julio de 1909 marcaron el fin de las insurrecciones urbanas y del terrorismo que había asolado a la ciudad durante los años anteriores. A partir de 1910, la violencia asumió un carácter netamente sindical, destacando el surgimiento de los llamados atentados sociales. ${ }^{26}$

La primera manifestación relevante y sistemática de los atentados sociales se registró durante el prolongado conflicto metalúrgico de 1910. Iniciado a finales de mayo como una huelga parcial en la fábrica de remaches "Unión Metalúrgica", en septiembre derivó en una huelga general del ramo que llegó a involucrar a casi 9.000 obreros, y que acabó en diciembre con una dura derrota para los metalúrgicos. El conflicto estuvo caracterizado por el amplio uso de la violencia y la coacción, consecuencia de la aspiración de unas sociedades de oficio minoritarias amovilizar a un enorme número de trabajadores. Las huelgas metalúrgicas de 1910 representaron uno de los episodios más violentos de la lucha sindical durante las primeras décadas del siglo XX: en los 196 días que duró el conflicto, alrededor de 117 personas fueron agredidas, de las cuales dos resultaron muertas y 45 heridas. $^{27}$

Las huelgas del metal introdujeron algunas importantes novedades en la praxis violenta del movimiento obrero barcelonés, marcando una ruptura con respecto al período anterior. De partida, el uso de armas de fuego había constituido un elemento más bien excepcional en los conflictos laborales, mientras en este caso se registraron disparos en 21 de los 46 episodios de violencia recopilados por Miguel Sastre. El aumento del empleo de medios letales evidenciaba una radicalización de las formas de lucha, pero también era la consecuencia de una transformación

${ }^{26}$ El testimonio del Gobernador en A. Ossorio: Barcelona, julio de 1909 (Declaración de un testigo), Imprenta de Ricardo Rojas, Madrid, 1910. Con respecto a la Semana Trágica, las principales obras de referencia son: J. Connelly Ullman: La Semana Trágica. Estudio sobre las causas socioeconómicas del anticlericalismo en España (1898-1912), Ariel, Barcelona, 1972; J. Romero Maura: La Rosa de fuego..., op. cit.;VVAA: Els fets de la Setmana Tràgica (1909). Actes de les jornades organitzades pel CHCC, 28 i 29 de maig de 2009, Centre d'Història Contemporània de Catalunya, Barcelona, 2010;A. Moliner (ed.): La Semana Trágica de Cataluña, Nabla, Alella, 2009.

${ }^{27}$ Una buena síntesis del conflicto, con una detallada relación de los episodios de violencia en $\mathrm{M}$. Sastre: Las huelgas en Barcelona y sus resultados durante los años 1910 al 1914 ambos inclusive, Editorial Barcelonesa, Barcelona, 1915, pp. 23-62. 
en las dinámicas de las agresiones. En particular, nos referimos a los atentados organizados en forma de emboscada, que requerían de una planificación sofisticada, eligiendo tanto el lugar de la agresión como los objetivos. Además, los ataques no se limitaron a los esquiroles, sino que incluyeron a encargados y empleados. Por ejemplo, uno de los hechos más graves de la huelga fue el siguiente:

Poco después de las seis de la tarde, hora en la que cesan en sus tareas los operarios de la fábrica de telas metálicas [de] los señores Rivière [...] abandonaron la fábrica cinco escribientes [...] Al llegar frente al café llamado "Familiar", salieron de una calleja contigua varios individuos, los cuales, sin mediar cuestión alguna, agredieron a los escribientes, haciéndoles casi a quema ropa crecido número de disparos de arma de fuego. Tres de los escribientes cayeron al suelo heridos, y mientras los otros dos, repuestos apenas del susto y sorpresa que la inesperada y brutal agresión les produjo, trataban de auxiliar a sus compañeros, los agresores se dieron a la fuga, $y$ amparados por la obscuridad de la noche consiguieron desaparecer. Atraídos por el ruido de las detonaciones, acudieron al lugar del suceso varias parejas de la guardia civil de caballería, de las que prestan servicio en aquella barriada, pero cuantas pesquisas hicieron para dar alcance a los fugitivos resultaron inútiles. ${ }^{28}$

Para comprender este aumento cuantitativo y cualitativo de la violencia sindical, es necesario considerar el contexto en que se desarrolló el conflicto, especialmente entre los meses de julio y noviembre. Los aniversarios de la Semana Trágica y de la ejecución de Ferrer i Guàrdia generaron un clima de esperanza y temor — según los puntos de vista - de que se repitiera una insurrección como la del año anterior. Por otra parte, una serie de importantes movimientos huelguísticos tanto en el Estado español como en el extranjero, además de la proclamación de la república en Portugal, contribuyeron a profundizar la sensación de un estallido inminente. En definitiva, 1910 fue un año marcado por la tensión y la polarización social en Barcelona, en un contexto, por lo demás, de reactivación del sindicalismo anarquista, el cual fortalecía sus estructuras organizativas a través de la creación en noviembre de la Confederación Nacional del Trabajo.

Además de estos aspectos, la radicalización de la violencia sindical durante los conflictos del metal estuvo relacionada con la irrupción de una nueva generación de militantes imbuidos de una noción vaga del sindicalismo revolucionario, que tendía a identificar acción directa con acción violenta. Se trataba un nuevo tipo de huelga en que la violencia ya no era un desafortunado subproducto de la lucha de clases, sino un eje central de la acción sindical. Esta radicalización del movimiento obrero afectó a distintos países europeos en los años anteriores a la Primera Guerra Mundial. De hecho, al momento de definir la nueva realidad de las agresiones la prensa barcelonesa optó con frecuencia por compararla a la chasse aux renards (caza de zorros), fenómeno que se había difundido en años anteriores

${ }^{28}$ La Vanguardia (Barcelona), 4 de noviembre de 1910, p. 3. 
en el seno de la CGT francesa. Sin embargo, cabe destacar que la práctica de los atentados organizados fue extremadamente rara en otros contextos. Al respecto, Antoni Rovira i Virgili criticó ásperamente esta relación entre sindicalismo y violencia durante el conflicto metalúrgico, refiriéndose en forma indirecta a ella al comentar la actuación de anarquistas y sindicalistas en Francia:

Desgraciadament, molts han confós l'esperit revolucionari ab l'esperit de violencia. Que s'admeti, en determinades circumstancies, l'apelació a la forsa, no vol dir que a cada moment hagi de pertorbarse l'ordre ab bullangues, ni que hagi d'erigirse en sistema la violencia colectiva $y$ individual. Això ja no es ser revolucionari: es ser violent. [...] El sindicalistes que a tota hora volen emplear l'acció directa, el sabotage, la cassa d'esquirols y l'agressió, demostren tenir una mentalitat perfectament reaccionaria. Treure les energies dels cervells y posarles en els punys no es obra d'avens ni de civilisació. Fer jugar a la forsa un paper preponderant en les lluites socials es descentrar la qüestió y portarla a un terreny perillosíssim, en el qual els obrers hi trobaran més per perdre que per guanyar. ${ }^{29}$

Por su parte, el Estado fue incapaz de gestionar el conflicto de manera satisfactoria. Si bien logró anular rápidamente la acción de los piquetes a través de un masivo despliegue de fuerzas de seguridad, se vio completamente sobrepasado por el fenómeno de los atentados sociales. Tal como habían demostrado los años del terrorismo, las autoridades no contaban con herramientas adecuadas para afrontar el fenómeno de la violencia organizada de pequeños grupos. Hábil en la represión de la movilización colectiva de masas, el Estado se encontraba más bien inerme ante los ataques de estos núcleos informales, por lo que el recurso al atentado social permitía también un amplio grado de impunidad. Al no contar con una policía investigativa decente, ni con una política fiable de infiltración en los sindicatos, las autoridades tan sólo lograban condenas cuando las detenciones se realizaban en el momento de cometer los hechos. En el caso concreto de los

${ }^{29}$ La Campana de Gràcia (Barcelona), 22 de octubre de 1910, p. 3. Rovira i Virgili describía la chasse aux renards del siguiente modo: "En aquets darrers temps els diaris parlen molt de la chasse aux renards. Aquestes paraules son franceses, però lo que elles signifiquen no passa a Fransa solament. Chasse aux renards vol dir cassa d'esquirols. Es la persecució dels obrers esquirols per part dels vaguistes. Alguns grups sindicalistes francesos, massa entusiastes de l'anomenada acció directa, han fet de la cassa d'esquirols un dels seus preferits medis de combat. [...] A Fransa, la cassa d'esquirols ha sigut metòdicament organissada en algunes vagues. Ha donat lloc a incidents còmics, y també a incidents tràgics. Fins han inventat els sindicalistes uns aparells especials pera castigar als esquirols. Un d'ells es la chausette à clous, que es un sabatot ple de claus, ab el qual els vaguistes copegen als que acudeixen al treball. Un altre es la machine à bosseler, que no es altra cosa que un gran garrot destinat a abonyegar (bosseler) el cap dels esquirols tossuts. El ciutadà Browning (nom que'l cèlebre Hervé ha donat als revòlvers y pistoles) juga també un paper important en la chasse aux renards. [...] Unes vegades els vaguistes agafen als esquirols y els tenen tancats un grapat d'hores. Altres vegades els fan comparèixer davant d'un tribunal en tota regla format per membres del sindicat", La Campana de Gràcia (Barcelona), 8 de octubre de 1910, p. 3. Con respecto a la movilización sindical en Europa durante estos años, ver D. Geary: European labour protest, 1848-1939, Croom Helm, Londres, 1981. 
metalúrgicos, de los 63 detenidos a raíz de las huelgas, 47 fueron procesados en el marco del sumario único instruido por el juez especial; sin embargo, tan sólo 9 de ellos enfrentaron finalmente un juicio. ${ }^{30}$

Ahora bien, la aparición de los atentados sociales no significó una generalización de la violencia en los conflictos laborales de la ciudad, que siguió constituyendo un hecho minoritario. Dada la dureza de las relaciones laborales en Cataluña, la huelga ofrecía un mecanismo de negociación colectiva basado en el conflicto, pero en el que la violencia no era un componente estructural. Durante los años anteriores a la Primera Guerra Mundial, las huelgas violentas se registraron en sectores que presentaban características especiales, como un carácter móvil que dificultaba una protección policial eficaz, o el empleo masivo de esquiroles, que tendía a transformar a las huelgas en una desesperada lucha por el puesto de trabajo. De hecho, de los 205 episodios de violencia sindical recogidos por Miguel Sastre entre 1910 y 1914, 137 (66,8\%) se concentraron en tan sólo cinco huelgas. ${ }^{31}$

En síntesis, el tradicional recurso al piquete y la acción colectiva había prácticamente desaparecido durante la primera década del siglo, dejando como principal alternativa las agresiones realizadas por pequeños grupos o individualidades. Generalmente, estos ataques se produjeron como hechos aislados y espontáneos, sin constituir un rasgo definitorio del conflicto. Para que el hecho puntual se transformase en sistemático se requería de algún tipo de factor desencadenante que modificase radicalmente el marco en que se desenvolvía la huelga. En este sentido, el surgimiento de los atentados sociales no parece indicar la aparición de grupos de especialistas en la violencia al interior de los sindicatos, sino más bien consideramos que eran el fruto de la acción autónoma de algunos huelguistas que compartían una concepción de la violencia como elemento necesario de la acción sindical. Por otra parte, era la expresión de transformaciones más profundas, que significaron el desplazamiento de la acción violenta de las franjas más radicales del movimiento obrero y libertario desde el terreno del terrorismo político al de la lucha de clases, contribuyendo a modificar las formas tradicionales de la violencia sindical.

\section{Los atentados del Ramo del Agua y los contramaestres de “El Radium”}

La violencia sindical en Barcelona sufrió algunas transformaciones importantes a partir de 1910, debido al surgimiento de atentados organizados que se mani-

\footnotetext{
${ }^{30} \mathrm{El}$ número de detenidos y procesados en M. Sastre: Las huelgas en Barcelona y sus resultados durante los años 1910 al $1914 \ldots$, op. cit., p. 85.

${ }^{31}$ Las cinco huelgas, todas ellas generales de oficio, fueron la de carreteros (1911 y 1914), metalúrgicos (1910), cocheros (1912) y carpinteros (1914). El listado detallado de los episodios de violencia durante estos años en M. Sastre: La esclavitud moderna..., op. cit., pp. 95-114.
} 
festaron, eso sí, en un reducido número de huelgas particularmente tensas. Sin embargo, el objetivo de las agresiones se mantuvo en buena medida invariado, es decir, esquiroles, trabajadores reacios a secundar la huelga y encargados. Durante la huelga del metal un directivo de la Maquinista fue apuñalado y al año siguiente hubo un atentado fallido contra un patrono carretero; sin embargo, los ataques contra empresarios en el contexto de conflictos laborales seguía siendo un hecho excepcional. Por ende, los sucesos que se registraron durante 1912 en el seno del sector de acabados de la industria textil, tradicionalmente conocido como Ramo del Agua, representaron un importante salto cualitativo en la violencia sindical barcelonesa. ${ }^{32}$

Desde finales del siglo XIX, la industria textil catalana había vivió profundas transformaciones en el proceso productivo impulsadas por los empresarios. Una verdadera ofensiva patronal, en palabras de Carles Enrech, que significó una masiva descualificación del sector intermedio de los trabajadores textiles, provocada por la introducción de nueva maquinaria y a la sustitución de oficiales varones por mano de obra femenina e infantil. A comienzos del siglo XX, dicho proceso se había completado en el sector del hilado y del tejido, aunque en el ramo de los acabados y entre los contramaestres el trabajador cualificado masculino logró mantener un rol predominante. En este sentido, durante estos años la problemática sindical de estos trabajadores estuvo centrada en una enconada y conflictiva defensa del oficio ante la amenaza patronal. En Barcelona, el Ramo del Agua se organizaba sindicalmente en torno a dos sectores: la Sociedad de Cilindradores, Aprestadores y demás acabados en piezas y la Unión de Tintoreros, Blanqueadores y sus anexos, fuertemente influenciadas por militantes anarquistas. En 1912, ambas sociedades sostuvieron una ofensiva sindical que se concluyó en modo desigual: mientras que en febrero los cilindradores y aprestadores obtuvieron la jornada de nueve horas, tintoreros y blanqueadores sufrieron una dura derrota en abril. A pesar de que estas huelgas no fueron violentas, cuando el fracaso de los tintoreros se hacía cada vez más inevitable se verificaron en pocas semanas cuatro atentados con armas de fuego contra empresarios. Los ataques no provocaron heridos y, de hecho, la mecánica de los atentados — disparos desde lejos contra coches y tartanas- induce a pensar en un acto intimidatorio más que en la efectiva intención de causar daño a los fabricantes. ${ }^{33}$

Tras la ráfaga de atentados, la situación se mantuvo calma a medida que los tintoreros abandonaban definitivamente la huelga. Improvisamente, la tranquilidad se vio interrumpida de forma dramática por el primer atentado mortal contra un

${ }^{32}$ Los atentados en La Vanguardia (Barcelona), 5 de octubre de 1910, p. 3 y 9 de febrero de 1911, p. 14.

${ }^{33}$ Con respecto a las transformaciones en la industria textil: C. Enrech: Indústria i ofici. Conflicte social $i$ jerarquies obreres a la Catalunya tèxtil (1881-1923). Universitat Autònoma de Barcelona, Bellaterra, 2005. Sobre las huelgas del Ramo del Agua en 1912 y los atentados: M. Sastre: Las huelgas en Barcelona y sus resultados durante los años 1910 al 1914..., op. cit., pp. 137-143. 
empresario en Barcelona durante el siglo XX. A finales de marzo los trabajadores de la fábrica de aprestos Bargalló iniciaron una huelga en protesta por el despido de los delegados de la sociedad obrera. El conflicto se desarrolló en modo tenso, debido al boicot organizado por el sindicato hacia la fábrica; sin embargo, no se registraron episodios de violencia, hasta la noche del 29 de abril en que uno de los propietarios de la fábrica, Carles Bargalló, fue asesinado en las puertas de su domicilio. ${ }^{34}$ A pesar de la innegable novedad que significaba un hecho de estas características, ni la patronal, ni los sindicatos ni las autoridades dieron demasiada importancia al acontecimiento, al menos a nivel público. El único que intuyó el peligro que podía entrañar la generalización de este tipo de episodios fue el fiscal del Tribunal Supremo Andrés Tornos, el cual en su Memoria para el año 1912 afirmaba lo siguiente con respecto a la "delincuencia societaria" en Barcelona:

Las coacciones, las lesiones, los daños, el incendio y hasta el asesinato fueron objeto de procedimiento. Todos estos atentados los comete el obrero contra los no inscriptos (sic) en las Sociedades de resistencia, o contra la propiedad de los patronos, o contra la vida de los mismos. [...] En el año anterior [1911] se asesinó a un esquirol, se envenenaron varios caballos cuando los carreteros se hallaban en huelga, y se atentó contra la vida de dos patronos, sin que el criminal obtuviera sus propósitos, por fortuna. Este año también se ha cometido un asesinato en la persona del patrono D. Carlos Bargalló, que quiera Dios no sea el principio de la senda que la clase obrera se propone seguir en lo sucesivo, senda mucho más tortuosa y criminal que la seguida hasta aquí, con serlo ésta mucho también. ${ }^{35}$

Al igual que la gran mayoría de los atentados sociales de esta época, resulta imposible establecer con certeza a los autores materiales. La noche del asesinato fueron detenidos los tintoreros Pere Bonet y Jaume Samsó en las cercanías del lugar de los hechos. La policía detuvo también como presuntos cómplices a varios dirigentes y afiliados del sindicato, sin embargo, sólo Bonet y Samsó fueron juzgados por la muerte de Bargalló. El juicio se llevó a cabo en mayo de 1913 y se concluyó con la absolución de los acusados por parte del jurado; no obstante, lo cierto es que ni Bonet ni Samsó ofrecieron explicaciones convincentes con respecto a la evidencia incriminatoria que la fiscalía había presentado en su contra. En este sentido, la hipótesis más factible es que ambos tintoreros se vieron involucrados en el atentado, probablemente bajo la dirección de Antoni Sevé (a) El Llarch. Sevé había sido uno de los organizadores del sindicato en la fábrica, siendo detenido durante la huelga debido a una denuncia del mismo Bargalló. La fiscalía consideraba a Sevé como el autor intelectual — sino material - del delito, aunque no logró reunir evidencia suficiente para llevarlo a juicio. De este modo, el "caso Bargalló" presentaría características similares a los principales atentados sociales

\footnotetext{
${ }^{34}$ La Publicidad (Barcelona), 30 de abril de 1912, p. 5.

${ }^{35}$ ABC (Madrid), 17 de septiembre de 1912, p. 9.
} 
anteriores a la época del pistolerismo, es decir, actos de violencia organizados en forma autónoma por jóvenes huelguistas, para los cuales el atentado constituía una forma de represalia más que una estrategia sindical definida. ${ }^{36}$

Tras la muerte de Bargalló, cesaron los atentados contra patronos del Ramo del Agua, aunque todavía hubo algunos hechos violentos atribuidos a miembros del sindicato. Durante el verano de 1912, se registró una huelga en la fábrica Arch, Aguilar y Pla, en la que fue asesinado el esquirol Joaquim Adelantado y una niña de dos años resultó muerta durante un ataque contra la casa de un guardia de seguridad, familiar de otro esquirol. A finales de 1913, fue hallado sin vida el cuerpo de Camil Piqué, obrero que había abandonado la sociedad de tintoreros para afiliarse a la Unión Profesional católica. Sin embargo, durante estos años la práctica de los atentados sociales disminuyó sensiblemente. El contexto creado por el estallido de la Primera Guerra Mundial - en particular el encarecimiento de las subsistencias-, estimuló una amplia movilización sindical, que recuperó formas de acción colectiva que desde hace mucho tiempo escaseaban en Barcelona, como el piquete masivo o el asalto a los talleres. Por otra parte, tras algunos años de ilegalización y desorganización, la CNT inició un proceso de reconstitución que derivó en una alianza con la UGT y en el anuncio de una huelga general para mediados de 1917, cuyo objetivo era el establecimiento de un nuevo régimen. ${ }^{37}$

Aunque para el movimiento obrero barcelonés 1917 estuvo marcado por el hito de la huelga general de agosto, durante la primera parte del año la atención se enfocó en un nuevo conflicto en el Ramo del Agua, donde se desarrolló un duro lockout entre marzo y julio. Las sociedades obreras consideraron que el cierre patronal constituía un ataque en su contra por parte de los empresarios, con el objetivo de desarticular la reorganización del sindicalismo textil en Cataluña. Esta interpretación, unida a la intensa agitación previa a la huelga general, contribuyó a generar un clima de tensión y polarización en el que la retórica sindical violenta contra los patronos fue constante y con muy pocos filtros, llegando incluso a amenazarse con el asesinato. Como señalaba Solidaridad Obrera: "Estamos cansados de que esta situación continúe y si para ello es necesario cazar los fabricantes como perros hidrófobos, lo haremos. No vale más la piel de cualquier burgués que la nuestra. Conque al tanto". ${ }^{38}$ Este tipo de afirmaciones se alejaban de la tradicional

\footnotetext{
${ }^{36}$ Una detallada crónica del juicio en La Vanguardia (Barcelona), El Progreso (Barcelona) y La Publicidad (Barcelona), 29-31 de mayo de 1913.

${ }^{37}$ Los atentados de 1912 en La Vanguardia (Barcelona), 2 de septiembre de 1912, p. 2 y 6 de septiembre de 1912,p. 2. Con respecto a la muerte de Camil Piqué, ver El Correo Catalán (Barcelona), 11 de diciembre de 1913, p. 1. Sobre la conflictividad laboral en la ciudad durante los primeros años de la guerra mundial: J. L. Martín Ramos: «De la tregua a la expansión reivindicativa: El arranque de la explosión huelguística en Barcelona (1914-1916)", Historia social, 5 (1989), pp. 115-128. Con respecto a la huelga general de 1917, ver J. Lacomba: La crisis española de 1917, Ciencia Nueva, Madrid, 1970.

${ }^{38}$ Solidaridad Obrera (Barcelona), $1^{\circ}$ de mayo de 1917, p. 2.
} 
sobriedad que la prensa obrera había reservado para el tratamiento de la violencia, reflejando el elevado grado de animadversión hacia los empresarios.

La creación de este clima resulta significativa, ya que durante 1917 se registró una nueva serie de atentados contra patronos y encargados en el sector textil, de consecuencias mucho mayores que en 1912. Un ciclo que reviste además particular relevancia, siendo señalado por algunos autores como el origen del pistolerismo organizado en Barcelona. ${ }^{39} \mathrm{Al}$ igual que con respecto al "caso Bargalló", no existen certezas sobre los responsables de los ataques, por lo que nuevamente debemos limitarnos a ofrecer una evaluación crítica de las informaciones disponibles. En este sentido, todo apunta a que el origen se encuentra en la constitución en marzo de 1916 del sindicato "El Radium", que agrupaba a los contramaestres del textil. Los contramaestres se habían caracterizado por su respaldo a los empresarios, especialmente en las huelgas; sin embargo, los últimos años habían visto el aumento de los ritmos de trabajo y la jornada laboral, mientras que los salarios reales disminuían debido a la inflación galopante. Desde sus inicios, "El Radium" hubo de enfrentarse con la hostilidad de los empresarios, siendo despedidos sus afiliados en cuatro de las principales fábricas de Sants. A su vez, la actuación de "El Radium" asumió el carácter violento de los atentados sociales, registrándose algunos ataques hacia contramaestres no asociados, entre los que destacó el asesinato de Llorenç Casas el 3 de agosto de 1916. Dada la intensa presión ejercida sobre los esquiroles a través de agresiones y una campaña en Solidaridad Obrera, éstos se vieron obligados prácticamente a vivir al interior de las cuatro fábricas de Sants, protegidos por la Guardia civil. A medida que el conflicto se estancaba, la tensión aumentó rápidamente, derivando en un abierto enfrentamiento durante los primeros meses de 1917. Se subsiguieron varios atentados que se prolongaron hasta la huelga general de agosto, destacando el asesinato de Frederic Roigé, esquirol de la España Industrial con fama de confidente, y la emboscada a las puertas de la fábrica Balet iVendrell en la que resultó herido el contramaestre Josep Ollé. ${ }^{40}$

Tras la huelga general de agosto, la represión golpeó duramente a la CNT, contribuyendo a desarticular temporalmente el movimiento sindical en la ciudad. Sin embargo, los atentados continuaron y dieron un salto cualitativo al incluir a varios empresarios del textil y del Ramo del Agua: el 8 de octubre fue asesinado el fabricante Joan Tapias Batllorí, el 30 de noviembre fue agredido Antoni Trinxet, resultando muerto su cochero Miquel Esquirol, y el 4 de enero de 1918 se rea-

\footnotetext{
${ }^{39}$ Por ejemplo, León-Ignacio: Los años del pistolerismo. Ensayo para una guerra civil, Planeta, Barcelona, 1981, p. 13. También, aceptando la importancia de los atentados de 1917, se ha puesto el acento en el asesinato de Josep Albert Barret como el comienzo de una nueva fase:A. Balcells: El Pistolerisme..., op. cit., p. 33-53. Respecto a los orígenes del pistolerismo, ver E. González Calleja: El máuser y el sufragio. Orden público, subversión y violencia política en la crisis de la Restauración (1917-1931), CSIC, Madrid, 1999, pp. 118-127.

${ }^{40}$ Sobre "El Radium" y los contramaestes: J. Marquès: Història de l'organització sindical tèxtil El Radium, La Llar del Llibre, Barcelona, 1989, y C. Enrech: Indústria i ofici..., op. cit., pp. 322-327.
} 
lizaron varios disparos, sin consecuencias, contra Geroni Figueras, director de la fábrica Busquets. Además, fueron asesinados el 24 de octubre Jaume Casadevall, hijo del encargado de la fábrica Bertrand y Serra, y el 27 de diciembre Joan Llopis, empleado de la casa Trinxet. Esta serie de ataques se concluyó con el atentado de mayor perfil hasta la fecha: el 8 de enero de 1918, caía muerto en una emboscada Josep Albert Barret, destacado empresario del metal, a la vez que presidente de la Sociedad de Industriales mecánicos y metalarios y de la Unión Española de Transformadores metalúrgicos. ${ }^{41}$

Las investigaciones policiales obtuvieron sus primeros frutos en febrero, cuando comenzaron a producirse algunas detenciones y confesiones, a partir de las cuales el juez especial Galo Ponte construyó una versión en la que, en forma más o menos directa, se relacionaban gran parte de los atentados ocurridos durante 1917. En líneas generales, las acusaciones afirmaban que los directivos de ciertas sociedades obreras habrían ofrecido importantes cantidades de dinero a algunos individuos para realizar los ataques. En este sentido, destacaron los hermanos Joaquim y Pere Vandellós, militantes sindicales señalados como autores materiales de los atentados a Casadevall, Trinxet y Barret, ordenados respectivamente por dirigentes de las sociedades de cilindradores, contramaestres y metalúrgicos. Los acusados denunciaron en repetidas ocasiones que las confesiones habían sido obtenidas en base a torturas, aunque igualmente varios de ellos fueron sometidos a juicio entre marzo y abril de 1919, resultando todos absueltos. ${ }^{42}$

La versión de la fiscalía resulta difícil de evaluar debido a la pérdida de los sumarios de instrucción; sin embargo, en líneas generales coincide con el testimonio de Ángel Pestaña, uno de los principales protagonistas del sindicalismo cenetista. Pestaña afirma que tras la huelga general de 1917, algunos militantes se mostraron disponibles para atentar contra empresarios, ofrecimiento que rechazó, aunque algunos sindicatos se mostraron favorables. Por otra parte, Pestaña sostiene que el asesinato de Barret fue organizado por el sindicalista metalúrgico Eduard Ferrer, confidente del comisario Manuel Bravo Portillo. Bravo, colaborador del espionaje alemán, habría elegido como objetivo a Barret debido a que producía municiones para los aliados; sin embargo, el mismo Pestaña reconoce que Ferrer convenció a

${ }^{41}$ Una relación de los atentados, así como los principales sospechosos, en el edicto judicial emanado por el juez Galo Ponte: La Veu de Catalunya (Barcelona), 21 de abril de 1918, ed. de la mañana, p. 9.

${ }^{42}$ Las principales crónicas de los juicios para el atentado a Oller en: ABC (Madrid), La Vanguardia (Barcelona) y La Veu de Catalunya (Barcelona), 11-14 de marzo de 1919; para el asesinato de Casadevall: ABC (Madrid), El Sol (Madrid), La Correspondencia de España (Madrid), La Vanguardia (Barcelona), 19-23 de marzo de 1919; para el atentado a Trinxet: La Vanguardia (Barcelona), 16 de abril de 1919, p. 5 y La Veu de Catalunya (Barcelona), 15 de abril de 1919, ed. de la mañana, p. 2. Para el asesinato de Barret hubo dos juicios, el primero en ABC (Madrid), 9-13 de abril de 1919; La Veu de Catalunya (Barcelona), 15 de abril de 1919, ed. de la mañana, p. 2; y el segundo en El Sol (Madrid), La Acción (Madrid), La Vanguardia (Barcelona), 21-27 de junio de 1919. 
cinco jóvenes sindicalistas para realizar el atentado, asegurándoles que era orden del sindicato y ofreciéndoles dinero para financiar una eventual fuga. ${ }^{43}$

Como vemos, la versión de Pestaña es perfectamente compatible con la de la acusación, exceptuando evidentemente la referencia al espionaje alemán. En este sentido, es interesante destacar que los atentados de 1917 estarían conectados en torno a un reducido número de dirigentes y militantes sindicales, que habrían adoptado el atentado personal como método de acción en un contexto de desorganización de las sociedades obreras tras la huelga general. Por ende, considerar estos ataques como el fruto de la acción de grupos organizados es probablemente errado, fruto de una proyección de las posteriores formas de violencia adoptadas durante el pistolerismo. Al igual en 1910 y 1912, los testimonios apuntan a acciones de represalia llevadas a cabo por pequeños grupos autónomos, en complicidad con algunos dirigentes sindicales. Aun así, los atentados de 1917 representaban una nueva ruptura en la evolución de la violencia sindical en Barcelona, ya que hasta entonces las agresiones habían encontrado su ámbito de legitimidad en el contexto de la huelga, por lo que al desligarse de ella se abrían una serie de inquietantes posibilidades.

\section{Conclusiones}

La violencia sindical en Barcelona durante las primeras décadas del siglo XX no fue un fenómeno inmutable, sino que sufrió importantes oscilaciones y transformaciones en el tiempo. En concreto, hemos analizado en el presente artículo uno de los ejes centrales de estos cambios: el surgimiento de formas de violencia individualizada y organizada en los conflictos laborales, que hacía finales de 1917 asumió unas características similares al fenómeno del pistolerismo. Una evolución que de ningún modo fue lineal, es decir, que los elementos reseñados en las páginas anteriores se encontraban evidentemente relacionados entre sí, pero no constituyen una secuencia causal, como si fueran los anillos de una cadena. Desde nuestro punto de vista, representaron hitos claves en la historia del movimiento obrero: tres momentos diferenciados que contribuyeron parcialmente a generar las condiciones para el sangriento enfrentamiento que se vivió en los años de la posguerra.

A comienzos del siglo, la acción sindical en Barcelona no presentaba un carácter especialmente violento, aunque las sociedades obreras demostraban una gran

${ }^{43}$ El testimonio de Ángel Pestaña en Trayectoria sindicalista, Tebas, Madrid, 1974, pp. 79-242; y El terrorismo en Barcelona (Memorias inéditas), Planeta, Barcelona, 1979, pp. 85-96. Sobre las relaciones de Bravo Portillo con el espionaje alemán, ver F. García Sanz: España en la Gran Guerra. Espías, diplomáticos y traficantes, Galaxia Gutenberg, Barcelona, 2014, pp. 209-219 y 316-322; y E. González Calleja y P. Aubert: Nidos de espías. España, Francia y la Primera Guerra Mundial, 1914-1919, Alianza, Madrid, 2014, pp. 331-364. 
capacidad de movilización. A partir de 1902, este potencial asumió un carácter amenazador para el régimen, ya que de un simple tema de orden público pasó a transformarse en un verdadero problema político. La consigna de la huelga general impulsada por los anarquistas se había demostrado como una eficaz plataforma para las fuerzas revolucionarias; sin embargo, la verdadera amenaza residía en la propia acción sindical, en cuanto incluso la huelga más pequeña podía expandirse y transformarse en general gracias a la movilización popular en las calles. La respuesta del Estado significó un vuelco en la política de orden público en la Ciudad Condal, pasando de una lógica centrada en la reacción a la violencia a otra caracterizada por la inhibición de la acción colectiva de los trabajadores, a través del control preventivo del territorio y de una serie de mecanismos de presión sobre las sociedades obreras. En muchos sentidos, esta nueva estrategia resultó exitosa: a pesar de la gran agitación de 1903 la nueva huelga general no se produjo y durante los años siguientes la conflictividad laboral descendió a niveles muy bajos.

Ahora bien, la violencia no era el fruto de la influencia de agitadores anarquistas sobre el movimiento obrero, sino más bien la expresión de la inestabilidad del sindicalismo de oficio. A través de la violencia, se intentaba compensar la debilidad sindical con la fuerza física, especialmente en el momento en que los huelguistas se veían incapaces de sostener la movilización de una parte significativa de los trabajadores. De este modo, la represión preventiva no logró erradicar la violencia de los conflictos laborales; por el contrario, tuvo como un efecto indeseado el multiplicarla y atomizarla a través de la acción de grupos reducidos de huelguistas. Evidentemente, no pretendemos sugerir que el Estado fuese el responsable directo de esta violencia, sino más bien resaltar que la acción colectiva de masas pretendía intimidar a los trabajadores que no secundaban la huelga a través de la fuerza del número y, por ende, el enfrentamiento constituía el resultado indeseado de su fracaso. En cambio, para el pequeño núcleo informal de huelguistas que se organizaba para cometer sabotajes o agresiones, la violencia se transformaba en su objetivo principal.

Un segundo punto de ruptura se registró a partir de 1910, con el surgimiento de ataques organizados con armas de fuego contra esquiroles, encargados y, si bien aún en modo esporádico, algunos empresarios. Cabe destacar que no toda la violencia sindical de estos años puede ser definida en base al concepto de atentado social. Por el contrario, buena parte de los episodios violentos con anterioridad a la Primera Guerra Mundial se concentró en los transportes y la construcción, manteniendo un carácter similar al del período anterior. Dado el carácter móvil o descentralizado de estos sectores, la policía podía evitar la acción de piquetes masivos, pero encontraba serias dificultades con respecto a los grupos reducidos que saboteaban carros, apaleaban esquiroles y asaltaban talleres. En este sentido, no es un caso que los atentados sociales se dieran inicialmente en sectores indus- 
trializados como el metal o el textil, donde la violencia organizada y planeada asomaba como una alternativa para superar el bloqueo de la acción colectiva por parte de las fuerzas de seguridad. Por otra parte, consideramos que la aparición de los atentados sociales estuvo relacionada con el contexto de polarización y radicalización de parte del movimiento obrero tras la Semana Trágica. En este sentido, resultó fundamental la difusión del sindicalismo revolucionario entre una nueva generación de jóvenes militantes, que buscaban superar el carácter pasivo que se atribuía a las sociedades de oficio. Un ideario que presentaba aún un aspecto vago y fragmentario, en el que destacaba la idea de acción directa como sinónimo acción violenta. ${ }^{44}$

La tercera ruptura en la violencia sindical estuvo determinada por los dos ciclos de atentados registrados en el sector del Ramo del Agua y de los contramaestres entre 1912 y 1917. Estos ataques presentaron un carácter decididamente más organizado, con una mayor implicación del sindicato —al menos a través de algunos dirigentes - y una ampliación de los objetivos, que por primera vez incluían en forma habitual a empresarios. Sin embargo, como hemos visto, estos elementos constituían la evolución exacerbada de algunas características de los atentados sociales de comienzos de la década, pero no eran elementos necesariamente novedosos. Por otra parte, la violencia en estos sectores se enmarcaba en un conflicto de larga duración en el mundo textil, iniciado por la ofensiva de los empresarios y la resistencia del trabajo masculino cualificado en defensa del oficio. Los atentados constituyeron una arista de esta pugna, la cual, eso sí, no tuvo continuidad inmediata tras 1917 ni influyó en un modo relevante durante los primeros años del pistolerismo. Desde nuestra perspectiva, la verdadera ruptura se dio en la desconexión de la violencia con el contexto de la huelga, donde hasta entonces había residido su legitimidad para el movimiento obrero. A pesar de las centenares de agresiones que se habían registrado desde comienzos de siglo, la cultura sindical distinguía claramente entre lo que consideraban un inevitable empleo de la fuerza durante los conflictos laborales y la violencia premeditada y organizada ejercida por especialistas. Al respecto, resulta ilustrativa la respuesta que Ángel Pestaña ase-

\footnotetext{
${ }^{44}$ En 1919, Ángel Pestaña todavía consideraba necesario destacar en sus conferencias que la violencia era sólo una característica secundaria de la acción sindical: "Se ha creído y se ha propagado, con marcado interés, que la acción directa es exclusivamente salir a la calle a dar palos a los esquiroles. No queridos compañeros, esto no es más que una fase de la acción directa: la acción directa es también otra. La acción directa en el orden de la discusión, es que los obreros traten directamente, sin intermediarios, sean éstos trabajadores o sean estos políticos o burgueses o autoridades, con aquellos con quienes tenemos el litigio pendiente", A. Pestaña: El terrorismo en Barcelona, seguido de Principios, medios y fines del sindicalismo comunista, Calamvs Scrpitorivs, Barcelona, 1978, pp. 49-50.
} 
gura haber dado a los militantes que le habían propuesto atentar contra patronos en 1917:

Comprendo - dije- el atentado personal cuando es el gesto de un hombre que en un momento dado de la historia quiere suprimir la vida de un tirano, de un liberticida, de un sojuzgador de pueblos. Lo comprendo, repito, y me lo explico, aunque no lo justifique ni vea en él tanta eficacia como otros han querido ver. Comprendo que durante una huelga o conflicto social, cuando las pasiones llegan al rojo vivo de la violencia, que tras una discusión, una disputa o una resistencia desesperada se llegue a este caso, no al atentado personal propiamente dicho, sino a la agresión que cueste la vida de un semejante, al que se cree responsable de la oposición a resolver el conflicto, o que traiciona la lucha. Pero de esto, que se ha dado muchas veces en la historia y que se dará muchas más aún, desgraciadamente, a lo que vosotros proponéis, o sea organizar metódicamente el atentado personal, media un abismo, que ni quiero, ni puedo, ni debo rebasar. ${ }^{45}$

En conclusión, entre 1902 y 1917 la violencia sindical en Barcelona se alejó de su dimensión colectiva, para luego asumir un carácter organizado bajo la forma del atentado social y, finalmente, desvincularse también del ámbito de la huelga. Se abría así una nueva fase, en el que el conflicto ya no se limitaba a la paralización del trabajo, sino que se transformaba en una pugna de poder constante entre sindicato y patronal. En este sentido, el fenómeno del pistolerismo representó un alejamiento definitivo de las formas tradicionales que la violencia sindical había asumido en Cataluña. Un salto que difícilmente se hubiera desarrollado de no mediar la radicalización derivada del contexto creado por la Primera Guerra Mundial, la revolución rusa, el crecimiento de la CNT y la respuesta de la patronal y del Estado. Ahora bien, las problemáticas enfrentadas por la acción sindical colectiva en Barcelona desde comienzos del siglo XX también contribuyeron a crear el ambiente necesario para el desarrollo de una violencia organizada e individualizada. Evidentemente, este ambiente no fue la causa directa de la situación que se creó a partir de 1919, aunque al mismo tiempo no es posible comprender la época del pistolerismo sin tomarlo en consideración.

${ }^{45}$ A. Pestaña: «Lo que aprendí en la vida», en Trayectoria sindicalista, op. cit., p. 121. 